\title{
Repairing skeletal muscle: regenerative potential of skeletal muscle stem cells
}

\author{
Francesco Saverio Tedesco,1,2 Arianna Dellavalle, ${ }^{1}$ Jordi Diaz-Manera, 1,3,4 \\ Graziella Messina,1,5 and Giulio Cossu1,5
}

\begin{abstract}
1Division of Regenerative Medicine, San Raffaele Scientific Institute, Milan, Italy. ${ }^{2}$ Vita-Salute San Raffaele and Open University, Milan, Italy. ${ }^{3}$ Hospital Santa Creu i Sant Pau, Neuromuscular Diseases Unit, Barcelona, Spain. ${ }^{4}$ Centro de Investigación Biomédica en Red sobre Enfermedades Neurodegenerativas (CIBERNED), Madrid, Spain. ${ }^{D}$ Department of Biology, University of Milan, Milan, Italy.
\end{abstract}

\begin{abstract}
Skeletal muscle damaged by injury or by degenerative diseases such as muscular dystrophy is able to regenerate new muscle fibers. Regeneration mainly depends upon satellite cells, myogenic progenitors localized between the basal lamina and the muscle fiber membrane. However, other cell types outside the basal lamina, such as pericytes, also have myogenic potency. Here, we discuss the main properties of satellite cells and other myogenic progenitors as well as recent efforts to obtain myogenic cells from pluripotent stem cells for patient-tailored cell therapy. Clinical trials utilizing these cells to treat muscular dystrophies, heart failure, and stress urinary incontinence are also briefly outlined.
\end{abstract}

\section{Introduction}

It has been known for more than a century that skeletal muscle, the most abundant tissue of the body, has the ability to regenerate new muscle fibers after it has been damaged by injury or as a consequence of diseases such as muscular dystrophy (1). Muscle fibers are syncytial cells that contain several hundred nuclei within a continuous cytoplasm. Therefore, whether the process of regeneration depends upon the fusion of mononucleated precursor cells or upon the fragmentation of dying muscle fibers, which release new cells, remained controversial for a long time, even after the demonstration by Beatrice Mintz and Wilber Baker (2) that multinucleated fibers are formed by the fusion of single cells. In 1961, Alexander Mauro (3) observed mononuclear cells between the basal lamina that surrounds each muscle fiber and the plasma membrane of the muscle fiber and named them satellite cells (SCs) (Figure 1). SCs were later accepted to be, and are still considered today, the main players in skeletal muscle regeneration. SCs also contribute to the postnatal growth of muscle fibers, which in adults contain approximately 6-8 times more nuclei than in neonates, all of them being irreversibly postmitotic.

In addition to SCs, other progenitors located outside the basal lamina, including pericytes, endothelial cells, and interstitial cells, have been shown to have some myogenic potential in vitro or after transplantation. The developmental origin of these progenitors is unclear, as is their lineage relationship with SCs, even though they may feed, to some extent, into the SC compartment (4).

There is much interest in understanding the cellular and molecular mechanisms underlying skeletal muscle regeneration in different contexts because such knowledge might help in the development of cell therapies for diseases characterized by skeletal muscle degeneration. These diseases include muscular dystrophy, the term for a group of inherited disorders characterized by progressive muscle wasting and weakness leading to a variable degree of mobility limitation, including confinement to a wheelchair and, in the most severe forms, heart and/or respiratory failure (5). Many muscular dystrophies arise from loss-of-function mutations in genes encoding cytoskeletal and membrane proteins, the most common

Conflict of interest: The authors have declared that no conflict of interest exists. Citation for this article: J. Clin. Invest. 120:11-19 (2010). doi:10.1172/JCI40373. and severe being Duchenne muscular dystrophy (DMD), which is caused by mutations in the gene encoding dystrophin, an integral part of a complex that links the intracellular cytoskeleton with the extracellular matrix in muscle. Muscular dystrophies are some of the most difficult diseases to treat, as skeletal muscle is composed of large multinucleated fibers whose nuclei cannot divide. Consequently, cell therapy has to restore proper gene expression in hundreds of millions of postmitotic nuclei (6).

In this Review, we discuss recent work indicating the possible existence of a stem/progenitor cell compartment in adult muscle (see also ref. 7) as well as studies related to the derivation of myogenic cells from embryonic and induced pluripotent stem cells (PSCs) for the development of new cell therapy strategies for diseases of skeletal muscle. An overview of clinical trials based upon transplantation of skeletal muscle stem cells is also provided. Neither the role of SCs in aging skeletal muscle nor the SC niche are discussed here due to space constraints, and readers are directed to excellent recent reviews on these topics by Suchitra Gopinath and Thomas Rando (8) and Michael Rudnicki and colleagues (9), respectively.

\section{SCs}

Identification and characterization. The most stringent way to classify cells as SCs remains by determining their anatomical location: SCs are found underneath the basal lamina of muscle fibers, closely juxtaposed to the plasma membrane (3). SCs originate from somites $(10,11)$, spheres of paraxial mesoderm that generate skeletal muscle, dermis, and axial skeleton, but the exact progenitor that gives rise to SCs remains to be identified. SCs are present in healthy adult mammalian muscle as quiescent cells and represent $2.5 \%-6 \%$ of all nuclei of a given muscle fiber. However, when activated by muscle injury, they can generate large numbers of new myofibers within just a few days (12). Quiescent SCs (13) express characteristic (although not unique) markers. In the mouse, the most widely used of these markers is the transcription factor paired box 7 (Pax7) (14), which is essential for SC specification and survival (15). In contrast, Pax3 is expressed only in quiescent SCs in a few specific muscle groups such as the diaphragm (16). The basic helix-loop-helix (bHLH) gene myogenic regulatory factor 5 (Myf5) is expressed in the large majority of quiescent SCs, and for this reason, mice expressing nuclear LacZ under the control of the Myf5 promoter (Myf $5^{\text {nlacz/+ }}$ mice) have 


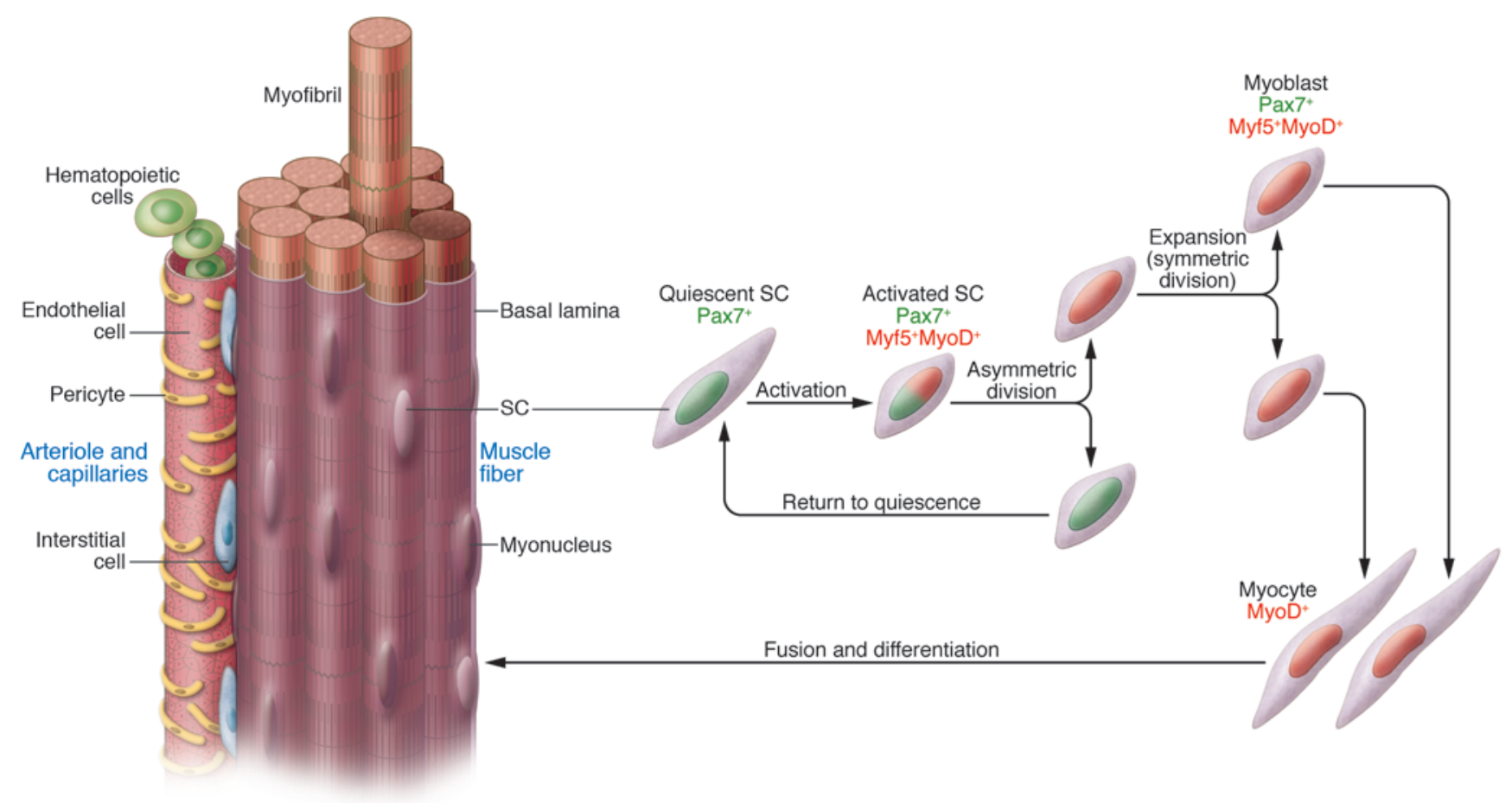

Figure 1

Asymmetric cell division during activation of SCs. This is a drawing representing the anatomy of a muscle fiber with adjacent small vessels. SCs and other myogenic cells (pericytes and hematopoietic, endothelial, and interstitial cells) are depicted. SC activation in vivo is followed by an asymmetric division, with $P a x 7, M y o D$, and $M y f 5$ being expressed in differentiating cells and Pax7 in cells returning to quiescence in order to maintain a pool of progenitors $(25,41)$.

been useful for identifying and characterizing SCs (17). Many other markers (18-29) have been identified and are listed in Table 1. Some of these surface markers are useful for isolating "purified" SC populations by cell sorting, but since each marker is not exclusively expressed on SCs, a combination of different markers must be used. Alternatively, transgenic mice such as those expressing GFP under the control of promoters that drive the expression of genes encoding SC markers - for example, the Pax 3 promoter - can be used to isolate SCs (29-31). In humans, markers of both quiescent and activated SCs do not fully correspond to those in the mouse, and relatively little is known about them due to the difficulty of obtaining human tissue. For example, although CD34 is a marker of SCs in mice, it does not mark SCs in human muscle (32); and M-cadherin is not as consistent a marker of SCs in humans as it is in mice. Among the more reliable markers of SCs in human muscle is CD56, although it also marks natural killer lymphocytes (33).

Activation. In response to a muscle injury, SCs are activated and start to proliferate; at this stage, they are often referred to as either myogenic precursor cells (mpc) or myoblasts $(34,35)$. Several signals, deriving both from damaged fibers and infiltrating cells, are involved in SC activation, including HGF (36), FGF (37), IGF (38), and NO (39).

The progression of activated SCs toward myogenic differentiation is mainly controlled by Myf5 and myogenic differentiation 1 (MyoD) (17) and is followed by fusion into regenerating fibers. The whole process takes approximately 7 days in the mouse (40), during which time SCs undergo different fates, giving rise to a few $\mathrm{Pax} 7^{+} \mathrm{MyoD}^{-}$cells, which return to quiescence (to maintain the progenitor pool), and many $\mathrm{Pax} 7^{+} \mathrm{MyoD}^{+}$cells, which are commit- ted to differentiation (41) (Figure 1). Notch signaling is thought to regulate this process through promotion of asymmetric divisions, although there is not agreement on the role of Numb (a Notch inhibitor and cell-fate determinant) in inducing differentiation (42) and sustaining self renewal (43). The occurrence of asymmetric cell division is also supported by the identification of a subpopulation of SCs able to retain BrdU after pulse-chase labeling, with some cells displaying selective template DNA strand segregation during mitosis $(43,44)$. In addition, Rudnicki and colleagues validated the label-retention model of SCs and demonstrated that approximately $10 \%$ of Pax $7^{+}$mouse SCs had never expressed Myf5 and that these cells remain adherent to the basal lamina during asymmetric mitosis, generating one Pax $7^{+} \mathrm{Myf5} 5^{-}$satellite "stem cell" and one Pax $7^{+} \mathrm{Myf5}^{+} \mathrm{SC}$ "progenitor," eventually destined to differentiate (25) (Figure 1). The same group also elegantly described Wnt7a as regulating the symmetric expansion of $\mathrm{Pax}^{+} \mathrm{Myf5}{ }^{-} \mathrm{SCs}(45)$.

Transplantation. Because of their features, SCs were considered obvious candidates for a cell-therapy approach to treating muscular dystrophy. Pioneer studies demonstrated that intramuscular injection of normal myoblasts (46) into $m d x$ mice, which lack dystrophin and are a model for DMD, resulted in fusion with host fibers and extensive dystrophin production. These studies led to several clinical trials in the early 1980s (see Muscular dystropbies section for details) that failed for a number of reasons, including poor survival and migration of donor cells after transplantation and rejection of the donor cells due to an immune response by the patients (47).

Many subsequent preclinical studies aimed to improve the survival, proliferation, and differentiation of the SCs after engraftment. For example, transplantation in dystrophic mouse mus- 
Table 1

SC markers

\begin{tabular}{|c|c|c|c|c|c|c|}
\hline Marker & SC expression & Localization & Function & $\begin{array}{l}\text { Prospective } \\
\text { isolation }{ }^{A}\end{array}$ & $\begin{array}{c}\text { Expression in } \\
\text { other tissues/cells }\end{array}$ & Ref \\
\hline Pax7 & $\begin{array}{c}100 \% \text { of quiescent and } \\
\text { activated SCs }\end{array}$ & Nucleus & $\begin{array}{l}\text { Transcription } \\
\text { factor }\end{array}$ & Pax7-GFP & Absent & 14 \\
\hline Pax3 & $\begin{array}{c}\text { Quiescent SCs } \\
\text { (only in a subset of muscles) }\end{array}$ & Nucleus & $\begin{array}{l}\text { Transcription } \\
\text { factor }\end{array}$ & Pax3-GFP & $\begin{array}{l}\text { Melanocyte } \\
\text { stem cells }\end{array}$ & 16 \\
\hline Myf5 & $\begin{array}{l}\text { Most quiescent SCs and all } \\
\text { proliferating SCs and myoblasts }\end{array}$ & Nucleus & $\begin{array}{l}\text { Transcription } \\
\text { factor }\end{array}$ & Myf5-nLacZ & Absent & 17 \\
\hline Syndecan-3 and -4 & $\begin{array}{l}98 \% \text { of quiescent } \\
\text { and activated SCs }\end{array}$ & Membrane & $\begin{array}{l}\text { Transmembrane } \\
\text { heparan sulfate } \\
\text { proteoglycan }\end{array}$ & $\begin{array}{l}\text { Cell } \\
\text { sorting }\end{array}$ & $\begin{array}{l}\text { Brain, dermis, BM, } \\
\text { bone, smooth } \\
\text { muscle, tumors }\end{array}$ & 18 \\
\hline VCAM-1 & Quiescent and activated SCs & Membrane & $\begin{array}{l}\text { Adhesion } \\
\text { molecule }\end{array}$ & $\begin{array}{l}\text { Cell } \\
\text { sorting }\end{array}$ & Activated endothelial cells & 19 \\
\hline c-met & Quiescent and activated SCs & Membrane & HGF receptor & Not used & Many tissues and tumors & 20 \\
\hline Foxk1 & Quiescent and activated SCs & Nucleus & Nuclear factor & Not used & Neurons & 21 \\
\hline $\mathrm{Cd} 34$ & Quiescent and activated SCs & Membrane & $\begin{array}{l}\text { Membrane } \\
\text { protein }\end{array}$ & $\begin{array}{c}\text { Cell } \\
\text { sorting }\end{array}$ & $\begin{array}{l}\text { Hematopoietic, endothelial, } \\
\text { mast, and dendritic cells }\end{array}$ & 13 \\
\hline M-cadherin & $\begin{array}{l}\text { Quiescent and activated SCs; } \\
\text { myoblasts }\end{array}$ & Membrane & $\begin{array}{l}\text { Adhesion } \\
\text { protein }\end{array}$ & Not used & Absent & 22 \\
\hline Caveolin-1 & $\begin{array}{l}\text { Quiescent and activated SCs; } \\
\text { myoblasts }\end{array}$ & Membrane & $\begin{array}{l}\text { Membrane } \\
\text { protein }\end{array}$ & Not used & $\begin{array}{l}\text { Endothelial fibrous and } \\
\text { adipose tissue }\end{array}$ & 23 \\
\hline$\alpha_{7}$ Integrin & $\begin{array}{l}\text { Quiescent and activated SCs; } \\
\text { myoblasts }\end{array}$ & Membrane & $\begin{array}{l}\text { Adhesion } \\
\text { protein }\end{array}$ & $\begin{array}{l}\text { Cell } \\
\text { sorting }\end{array}$ & $\begin{array}{l}\text { Vessel-associated } \\
\text { cells }\end{array}$ & 24 \\
\hline$\beta_{1}$ Integrin & Quiescent and activated SCs & Membrane & $\begin{array}{l}\text { Adhesion } \\
\text { protein }\end{array}$ & $\begin{array}{l}\text { Cell } \\
\text { sorting }\end{array}$ & Many tissues & 25 \\
\hline Cd56 & $\begin{array}{l}\text { Quiescent and activated SCs; } \\
\text { myoblasts }\end{array}$ & Membrane & $\begin{array}{l}\text { Homophilic binding } \\
\text { glycoprotein }\end{array}$ & $\begin{array}{l}\text { Cell } \\
\text { sorting }\end{array}$ & $\begin{array}{l}\text { Glia, neurons, and } \\
\text { natural killer cells }\end{array}$ & 26 \\
\hline $\mathrm{SM} / \mathrm{C} 2.6^{\mathrm{B}}$ & $\begin{array}{l}\text { Quiescent and activated SCs; } \\
\text { myoblasts }\end{array}$ & Unknown & Unknown & $\begin{array}{l}\text { Cell } \\
\text { sorting }\end{array}$ & Unknown & 27 \\
\hline Cxcr4 & Subset of quiescent SCs & Membrane & $\begin{array}{l}\text { SDF1 } \\
\text { receptor }\end{array}$ & $\begin{array}{l}\text { Cell } \\
\text { sorting }\end{array}$ & $\begin{array}{l}\text { HSCs, vascular endothelial } \\
\text { cells, and neuronal cells }\end{array}$ & 28 \\
\hline Nestin & $\begin{array}{c}\text { Around } 98 \% \text { of quiescent SCs } \\
\text { and myoblasts }\end{array}$ & $\begin{array}{l}\text { Intermediate } \\
\text { filament }\end{array}$ & $\begin{array}{l}\text { Intermediate } \\
\text { filament protein }\end{array}$ & $\begin{array}{l}\text { Nestin } \\
\text { GFP }\end{array}$ & Neuronal precursor cells & 29 \\
\hline
\end{tabular}

AProspective isolation: direct isolation of cells from tissue, usually based upon cytofluorimetric sorting with antibodies directed against cell surface markers. BNovel monoclonal antibody directed against an unknown antigen present on SCs. Foxk1, forkhead box $\mathrm{k} 1$.

cles of a single muscle fiber that contained as few as seven SCs led to an increasing number of new SCs that in turn generated more than 100 new muscle fibers and could also be activated after injury (48). This is a much more efficient way to generate new muscle fibers than transplantation of cultured SCs, in which normally the number of donor-derived new fibers that are generated is several orders of magnitude less than the number of injected cells. Unfortunately, this method would be difficult to translate into clinical protocols.

In the past few years, several groups have succeeded in prospectively isolating "pure" populations of SCs by using a combination of different markers (Table 1), such as Pax3-GFP (30), CXCR4 and $\beta_{1}$ integrin (49), $\alpha_{7}$ integrin and CD34 (50), or syndecan-3 and -4 (51). It is still unknown whether the different protocols allow isolation of the same cell population, enriched to different extents for a more primitive "stem-like" fraction. However, all these studies revealed that freshly isolated cells have a much greater capacity to generate dystrophin-expressing fibers in $m d x$ mice than the same cells after in vitro expansion (30); the simplest explanation for this is that the "stem" fraction either dies in culture or generates differentiation-committed SCs. Importantly, a short culture period of 3-4 days, without subculture, allowed lentiviral-mediated transduction and thus genetic correction of SCs freshly isolated from $m d x$ mice, without compromising myogenic potency in vivo (52). Despite these encouraging results, previous unsolved problems still prevent the use of SCs to systemically treat patients with muscular dystrophy: in particular, the inability of these cells to cross the endothelial wall makes systemic delivery impossible and prevents possible healing of the diaphragm and cardiac muscles, both critical for patient survival (34).

\section{Other myogenic progenitors}

The availability of cell-autonomous, tissue-specific transgenic markers allowed the unequivocal demonstration of the existence of myogenic progenitors originating from tissues other than skeletal muscle (53). Upon transplantation (either BM transplantation [BMT] or direct injection into skeletal muscle), these cells, identified by transgene expression, participate in muscle regeneration in wild-type and/or dystrophic mice (Figures 1 and 2; Table 2) and eventually enter the SC pool. The possibility that myogenic differentiation may depend upon fusion (and hence exposure to the dominant activity of MyoD) remains, but for skeletal muscle, this would be part of the physiological mechanism that creates the tissue. Below, we describe briefly some examples of these unorthodox myogenic cells. 


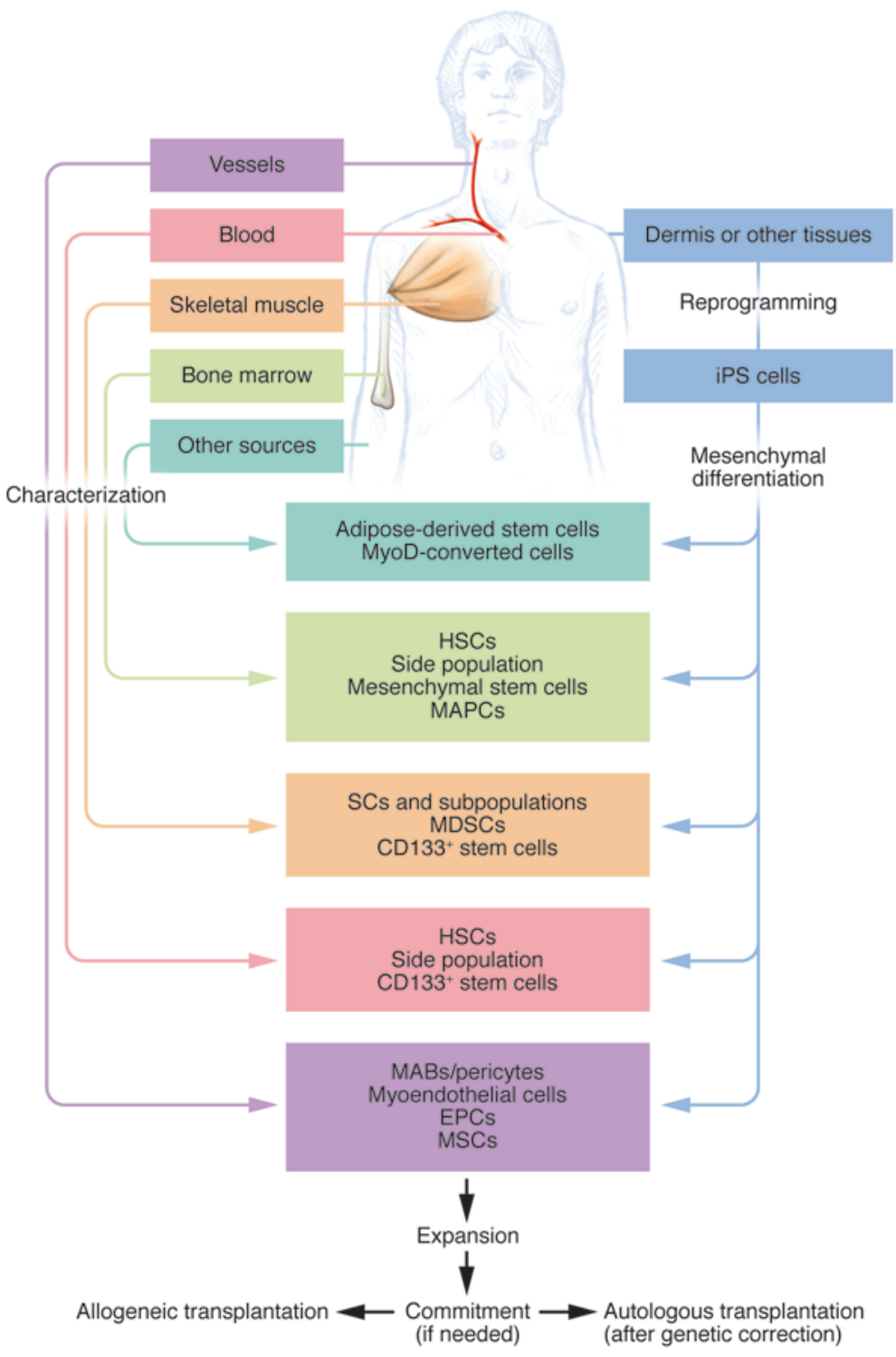

Figure 2

Derivation of different stem cells for possible use in skeletal muscle regeneration. The figure shows a flow chart with the sources of different myogenic stem cells. The possibility of deriving the same cells from a reprogrammed cell of the dermis is also outlined (blue boxes and arrows). Once obtained, the stem cells can be characterized, expanded, genetically corrected, and transplanted.

Cells from ectoderm: neural stem cells. To date, neural stem cells (both murine and human) are the only ectoderm-derived stem cells that have been shown to differentiate into skeletal muscle when cocultured with skeletal myoblasts or transplanted into regenerating skeletal muscle (54). Interestingly, cells expressing Myf5 exist in the brain and spinal cord, suggesting a cryptic potency that becomes apparent in vitro (55).

Hematopoietic cells. The first evidence of in vivo generation of skeletal muscle from BM cells was reported in 1998 (56) in a study that used transgenic mice expressing a nuclear $L a c Z$ under the control of the striated muscle promoter myosin light chain $1 / 3$ fast $(M L C 3 f)$. After transplantation of BM from the transgenic mice and subsequent injury to the host muscle, unequivo- cal $\beta$-gal-positive nuclei were detected in regenerated fibers, demonstrating that murine BM contains transplantable progenitors that can be recruited to an injured muscle through the circulation, where they participate in muscle repair (56). This opened the possibility of treating muscular dystrophy by BMT, but work in mice indicated that, unfortunately, the frequency of this event was too low, even in a chronically regenerating dystrophic muscle and even if the side population (SP) progenitor-enriched fraction was transplanted $(57,58)$. To address this issue, subsequent experiments were directed to identifying a rare, potentially highly myogenic progenitor, but those studies have so far had modest success. The hematopoietic, $\mathrm{CD} 45^{+}$fraction of the $\mathrm{BM}$ has been identified as the cell population with myogenic potential (59), and retrospective analysis in a DMD patient that had undergone BMT confirmed the persistence of donorderived skeletal muscle cells over a period of many years, again at very low frequency (60). Together, these data suggested that HSCs or a yet-to-be-identified cell that expresses several markers in common with true HSCs has myogenic potential. More recent approaches confirmed that hematopoietic cells have myogenic potential but disagreed on the stage at which myogenic differentiation would occur. One study reported that the progeny of a single mouse hematopoietic progenitor cell can both reconstitute the hematopoietic system and contribute, at low frequency, to muscle regeneration (61). However, a similar study showed that in response to injury, $\mathrm{CD} 45^{+}$hematopoietic progenitors contribute to regenerating mouse skeletal muscle through fusion of mature myeloid cells rather than fusion of the HSCs (62).

A subpopulation of circulating cells expressing CD133 (also known as Ac133), a well-characterized marker of HSCs, also expresses early myogenic markers (63). When injected into the circulation of dystrophic scid/mdx mice, $\mathrm{CD} 133^{+}$cells have been found to contribute to muscle repair, recovery of force, and replenishment of the SC pool. The group that discovered this also isolated a population of muscle-derived stem cells (MDSCs) expressing CD133 (64). Furthermore, when CD133+ cells from DMD patients were genetically corrected by lentivirus-mediated exon skipping for dystrophin exon 51 , these cells were able to mediate morphological and functional recovery in $s c i d / m d x$ mice (64). Thus, different subpopulations of hematopoietic cells, whose characterization is still incomplete, seem to possess myogenic potency, but none of these exhibit this property at high frequency.

Cells derived from mesoderm (other than hematopoietic cells). Many different types of mesoderm stem/progenitor cells have been shown to exhibit myogenic potential, usually after drug treatment, genetic modification, or coculture with SCs or myoblasts. In some cases, evidence of in vivo myogenesis has been documented. The list of such cells includes mesenchymal stem cells (MSCs), multipotent adult progenitor cells (MAPCs), MDSCs, CD133+ cells, mesoangioblasts (MABs), endothelial progenitor cells (EPCs), and adipose-derived stem cells, all of which are briefly described below or in Table 2. More details can be found in previous reviews $(6,32)$. 


\section{Table 2}

Properties of myogenic progenitors other than SCs

\begin{tabular}{|c|c|c|c|c|c|c|}
\hline Cell type & Origin & Proliferation & $\begin{array}{l}\text { In vitro myogenic } \\
\text { differentiation }\end{array}$ & $\begin{array}{c}\text { Dystrophin } \\
\text { expression in vivo }\end{array}$ & $\begin{array}{l}\text { Systemic } \\
\text { delivery }\end{array}$ & Ref \\
\hline CD133+ & Blood/skeletal muscle & Low/high & Induced by muscle cells /spontaneous & Yes & Yes & 64 \\
\hline EPC & Vessel wall & Low & Induced by muscle cells & Not tested & Yes & 71 \\
\hline HSC & BM & Low & Induced by muscle cells & Yes & Yes & 56 \\
\hline MAB & Vessel wall & High & Induced by muscle cells/spontaneous & Yes & Yes & 68 \\
\hline MADS & Adipose tissue & High & Spontaneous & Yes & Not done & 74 \\
\hline MAPC & Vessel wall & High & Induced by Aza-cytidine & Not tested & Not done & 32 \\
\hline MDSC & Skeletal muscle & High & Induced by muscle cells & Yes & Not done & 32 \\
\hline MEC & Vessel wall & High & Spontaneous & Yes & Not done & 73 \\
\hline MSC & Vessel wall & High & Induced by Aza-cytidine & Yes & Not done & 65 \\
\hline
\end{tabular}

MEC, myoendothelial cell.

MSCs have been shown to be capable of skeletal myogenesis (65). However, recently, Perlingeiro and colleagues demonstrated that although Pax3 activation enabled the in vitro differentiation of murine and human MSCs into $\mathrm{MyoD}^{+}$myogenic cells, these cells failed to cause functional muscle recovery in $m d x$ mice, despite good engraftment (66). The reason for this failure remains unclear.

MABs are vessel-associated progenitors (67) that express early endothelial markers when isolated from the embryo and pericyte markers when isolated from postnatal tissues. Since MABs are able to cross the vessel wall and are easily transduced with lentiviral vectors, they have been used in preclinical models of cell therapy for muscular dystrophy. Intraarterial delivery of either wild-type or genetically corrected MABs morphologically and functionally ameliorated the dystrophic phenotype of mice lacking $\alpha$-sarcoglycan (Sgca), which model limb-girdle muscular dystrophy 2D, a muscular dystrophy caused by mutations in the SGCA gene (68). In addition, intraarterial delivery of wild-type postnatal canine MABs resulted in extensive recovery of dystrophin expression and ameliorated pathologic muscle morphology and function in golden retriever dogs that model DMD (69). Similar cells have been isolated from human postnatal skeletal muscle and shown to represent a subset of pericytes and to give rise to dystrophin-positive muscle fibers when transplanted into $s c i d / m d x$ mice (70). Based on these studies, a phase I clinical trial with MAB allotransplantation in DMD patients is planned for the near future.

Initially identified as circulating cells expressing CD34 and fetal liver kinase-1 (Flk-1; also known as VEGFR2), EPCs (71) were shown to be transplantable and to participate actively in angiogenesis in various physiologic and pathologic conditions (71). It was then shown that freshly isolated human cord blood $\mathrm{CD} 4^{+}$cells injected into ischemic adductor muscles gave rise not only to endothelial but also to skeletal muscle cells in mice (72). Consistent with this, Péault and colleagues have identified cells with high myogenic potential within the vascular endothelium of human adult skeletal muscle (73). These human myoendothelial cells, which represent less than $0.5 \%$ of the cells in dissociated adult skeletal muscles, expressed both myogenic and endothelial cell markers $\left(\mathrm{CD} 56{ }^{+} \mathrm{CD} 34^{+} \mathrm{CD} 144^{+} \mathrm{CD} 45^{-}\right)$, exhibited long term proliferation, had a normal karyotype, and when transplanted into scid mice, were able to regenerate fibers in injured muscle (73).

Human multipotent adipose-derived stem (hMADS) cells, isolated from adipose tissue, differentiate into adipocytes, osteo- blasts, and myoblasts (74). Recently, the myogenic and muscle repair capacities of hMADS cells have been enhanced by transient expression of MyoD (75). The easy availability of their tissue source, their strong capacity for expansion ex vivo, their multipotent differentiation, and their immune-privileged behavior suggest that hMADS cells could be an important tool for cell-mediated therapy for skeletal muscle disorders.

\section{PSCs for muscle regeneration}

PSCs can give rise to all cell types. Among the various PSCs, we limit our discussion to ES cells $(76,77)$ and induced pluripotent stem (iPS) cells (78), as they are, in practice, the two types of PSC most commonly used to direct differentiation toward a given cell type, skeletal muscle, for the purpose of this Review. PSCs hold tremendous hopes for the cell therapy of degenerative diseases; and iPS cells further offer the possibility of deriving patient-specific PSCs (79) to study diseases in vitro (80) and the potential for genetic correction for autologous cell therapy.

Turning PSCs into skeletal muscle. A critical step in establishing the potential of PSCs as a therapeutic for skeletal muscle diseases is the development of techniques for the differentiation of these cells into tissue-specific progenitors suitable for transplantation. The most elegant way to obtain specific transplantable cell types is by exposing them in vitro to the same molecules that control their in vivo commitment during embryogenesis (reviewed in ref. 81), although the empirical testing of molecules and substrates could generate equally useful cells.

Seminal studies from the mid-1990s described how ES cellderived embryoid bodies (EBs), tridimensional structures formed when ES cells are grown in the absence of an embryonic fibroblast feeder layer, contained multinucleated muscle fibers that express skeletal muscle myosin heavy-chain genes $(82,83)$. Ten years later, it was documented for the first time in vivo that intramuscular injection of mouse EBs cocultured with $m d x$ muscle-derived progenitors in $m d x$ mice led to the production of a few clusters of donor-derived dystrophin-positive fibers (84). Recently, Studer and coworkers have derived transplantable myoblasts from human ES cells (85), while Chang and colleagues have generated transplantable satellite-like cells from mouse ES cells (86). Upon transplantation into $m d x$ mice, the latter cells have been found to regenerate acutely and chronically injured muscle and could also be secondarily transplanted (86). MyoD-mediated myogenic conversion of ES cell-derived cells is another intriguing approach, 
Table 3

Clinical trials of myoblast transplantation in DMD patients

\begin{tabular}{|c|c|c|c|c|c|c|c|c|c|}
\hline Author & Year & Blind & $\begin{array}{c}\text { Number } \\
\text { of pts }\end{array}$ & Pt age & $\begin{array}{c}\text { Drugs } \\
\text { administered }\end{array}$ & $\begin{array}{c}\text { Number of } \\
\text { myoblasts }\left(\times 10^{6}\right)\end{array}$ & $\begin{array}{l}\text { Expression of } \\
\text { dystrophin }\end{array}$ & $\begin{array}{l}\text { Improved } \\
\text { strength }\end{array}$ & Ref \\
\hline Law & 1991 & No & 3 & $9-10$ & Cyclosporine & 8 & $\begin{array}{l}3 / 3 \text { by IHC and } \\
\text { WB at } 3 \text { months }\end{array}$ & $\begin{array}{l}3 / 3 \text { patients } \\
\text { at } 3 \text { months }\end{array}$ & 95 \\
\hline Huard & 1992 & No & 4 & $13-20$ & None & 25 & $\begin{array}{l}3 / 4 \text { by IHC and WB } \\
\text { at } 4 \text { months (up to } \\
80 \% \text { fibers positive) }\end{array}$ & $3 / 4$ patients & 96 \\
\hline Law & 1992 & No & 21 & $6-14$ & Cyclosporine & 5000 & Not evaluated & $\begin{array}{c}43 \% \text { muscles } \\
\text { examined improved }\end{array}$ & 98 \\
\hline Gussoni & 1992 & Yes & 8 & $6-10$ & None & 100 & $3 / 8$ by PCR at 1 month & Not evaluated & 99 \\
\hline Karpati & 1993 & Yes & 8 & $6-10$ & Cyclophosphamide & 55 & $\begin{array}{c}\text { 0/8 by IHC at } \\
\text { 1-year follow-up }\end{array}$ & $3 / 8$ & 97 \\
\hline Tremblay & 1993 & Yes & 5 & $4-9$ & None & $100-240$ & $\begin{array}{l}3 / 4 \text { by IHC at } 1 \text { month } \\
\text { (up to } 36 \% \text { fibers positive); } \\
1 / 4 \text { by IHC at } 6 \text { months }\end{array}$ & $0 / 5$ & 100 \\
\hline Morandi & 1995 & Yes & 3 & $6-9$ & Cyclosporine & 55 & $0 / 3$ by IHC or PCR & Not evaluated & 101 \\
\hline Mendell & 1995 & Yes & 12 & $5-9$ & Cyclosporine & 110 & $1 / 12$ by IHCA & $0 / 12$ & 102 \\
\hline Miller & 1997 & Yes & 10 & $5-10$ & Cyclosporine & 100 & $\begin{array}{l}3 / 10 \text { by PCR at } 1 \text { month; } \\
1 / 10 \text { at } 6 \text { months }\end{array}$ & $0 / 10$ & 103 \\
\hline Neumeyer & 1998 & Yes & $6^{B}$ & $>21$ & Cyclosporine & $73-100$ & $0 / 3$, by IHCC & $0 / 3$ & 94 \\
\hline Skuk & 2006 & Yes & 9 & $8-17$ & Tacrolimus & 30 & $\begin{array}{l}\text { 8/9 patients by IHCC } \\
3.5 \%-26 \% \text { fibers } \\
\text { expressed dystrophin }\end{array}$ & Not evaluated & 104 \\
\hline
\end{tabular}

Pt, patient; IHC, immunohistochemistry; WB, Western blot. AMultiple injection site protocol. BStudy performed with Becker muscular dystrophy patients.

CIHC was performed using a peptide-specific antibody recognizing only donor dystrophin.

whose proof of principle dates to the early 1990s (87). On this front, Perlingeiro and colleagues recently achieved in vivo skeletal muscle differentiation from purified PDGFR $\alpha^{+} \mathrm{Flk} 1^{-}$progenitors isolated from EBs generated from mouse ES cells containing an inducible Pax3 gene (88). At the time of writing, there are no reports on the generation of myogenic cells from iPS cells, but assuming that the present protocols for ES cells can be adapted for iPS cells, we believe that in the next months, papers on this topic are likely to appear.

Muscle regeneration from ES/iPS cells via mesodermal progenitors. There is a large body of evidence indicating the existence of nonconventional muscle progenitors (see Other myogenic progenitors). Thus, the possibility of deriving mesodermal myogenic progenitors (89) from ES/iPS cells offers an alternative route for cell therapy for skeletal muscle regeneration. This approach has the advantage of producing myogenic progenitors that could be delivered systemically through the circulation.

In 2005, Studer and colleagues described the derivation from ES cells of mesenchymal precursors (90) that differentiated in vitro into different mesodermal lineages, including skeletal muscle. A recent article described the derivation from mouse ES cells of PDGFR $\alpha^{+}$ mesodermal progenitors that, after in vivo transplantation, expressed markers of SCs and contributed to muscle regeneration (91).

Issues to be solved. Despite the excitement for these novel strategies for treating degenerative muscular conditions, a number of safety and efficacy issues, some common to other cells (immunogenicity, survival, and differentiation), some prominent for ES/iPS cells, such as tumor formation, still need to be solved. For example, cytofluorimetric purification of committed progenitors (88) may dramatically decrease the possibility of transplanting undifferentiated tumorigenic cells. The use of standardized protocols for generat- ing iPS cells (92), together with stringent tumorigenic assays for the derived cell types, will certainly be a fundamental step toward their clinical application.

\section{Skeletal muscle stem cells: past and ongoing clinical trials}

Until now only SCs, and, to a very minor extent, $\mathrm{CD} 133^{+}$cells have been used in human clinical trials. The pathologies treated include forms of muscular dystrophy, heart failure associated with myocardial infarction (HFMI), and stress urinary incontinence (SUI).

Muscular dystrophies. In 1990, Peter Law and collaborators reported the first SC transplant in a 9-year-old boy affected by DMD, showing safety and dystrophin production (93). Soon after, 11 clinical trials in DMD patients were conducted using intramuscular injection of SCs (Table 3) (94-104). Although there were no adverse effects, new dystrophin production was demonstrated in many but not all cases and clinical benefit in none $(6,105)$. This is not surprising considering that intramuscular injection in several locations of a single muscle (or at most a few muscles) cannot elicit a general effect, although improved strength of the injected muscles was detected in $15 \%$ of the patients treated. Treating muscular dystrophies by intramuscular injection of myoblasts presents several problems that have not been solved yet. First, intramuscular injected cells distribute locally, implying that a huge number of injections will have to be performed in order to treat a complete muscle (96). Second, immune responses toward the injected SCs have been described, even in the case of major histocompatibility locus coincidence. Finally, the rapid death of most of the SCs in the first 72 hours after injection has been extensively reported $(106,107)$. Subsequent experimentation has been devoted to solving these problems, and a phase I clinical trial has been com- 
pleted (104). Although encouraging results have been obtained, this method is still limited by the impossibility of delivering myoblasts systemically through the circulation. Recently, Torrente and colleagues reported the first $\mathrm{CD} 133^{+}$cell transplant (108). They designed a phase I double-blind trial with an autologous transplant of unmodified, and thus still dystrophic, muscle-derived $\mathrm{CD}_{133^{+}}$cells in 8 boys affected by DMD exclusively to test safety; and indeed, no adverse events were reported.

Heart failure. Among different options to treat heart infarction, skeletal muscle-derived myoblasts were considered an optimal cell therapy, as they can be easily obtained from the same patient (avoiding the need for long-term immune suppression), rapidly expanded in vitro, and transplanted back in the patient heart. Preclinical experiments performed in animal models demonstrated their ability to engraft correctly, survive in postinfarction scars, differentiate into contractile skeletal muscle cells, and improve heart function (109-111), possibly also because they release angiogenic factors. Unfortunately, in these models, myoblasts were not able to differentiate into cardiomyocytes and did not integrate electrically with the host cardiomyocytes $(112,113)$. Despite this significant problem, several nonrandomized clinical trials using myoblasts to treat the infarcted heart demonstrated thickening of the $\mathrm{LV}$, an increase in LV ejection fraction, and prevention of LV dilatation, with clinical improvement in some patients (114-120). Histological analysis showed the presence of new myofibers in the scar zone expressing skeletal muscle-specific myosin heavy chain (121). In general, the transplantation procedure was clinically well tolerated, but a high incidence of arrhythmias, some of which were fatal, was reported. In 2007, the results of the MAGIC study, an international phase II double-blind trial were published (122). Ninety-seven patients affected by HFMI were randomized to receive placebo, a low dose of myoblasts $\left(400 \times 10^{6}\right.$ cells $)$, or a high dose of myoblasts $\left(800 \times 10^{6}\right.$ cells $)$. LV end-diastolic volumes decreased substantially in patients receiving myoblasts, supporting a role for myoblasts in remodeling of the heart muscle. The incidence of secondary events, including arrhythmias, was not different between the groups, although all patients received the antiarrhythmic agent amiodarone and were implanted with a cardioverter defibrillator. The results of the CAuSMIC (123) and SEISMIC trials (124) have demonstrated safety and some clinical improvement. Ongoing trials include the MARVEL study, a phase II/III randomized, double-blind, placebo-controlled trial for which results are expected during the fall of 2009.

SUI. SC-derived myoblasts have also been used as cell therapy for individuals with SUI, which is characterized by the loss of small amounts of urine upon coughing, laughing, sneezing, exercising, or other movements that increase intraabdominal pressure. Myoblasts may represent an interesting approach for the treatment of this disease (125), as the main cause of SUI is impaired tone of the urethral smooth and striated muscle, which is associated with atrophy of the supporting structures of the urethra, the mucosa, and vascular submucosa $(126,127)$. Treatment of SUI with SC-derived myoblasts has been performed using two different strategies: injection of autologous myoblasts to improve the sphincter tone; and injection of myoblasts together with fibroblasts (isolated by differential adhesion from the same muscle biopsy) to both improve sphincter tone and treat mucosa atrophy. Until now, all published studies have been nonrandomized, open studies, demonstrating a remarkable clinical improvement in most of the patients treated $(127,128)$. Moreover, structural and functional techniques have demonstrated thickening of the urinary sphincter and an increase in maximum urethral closure pressure. The onset of improvement is not immediate and may be delayed up to six months after cell injection; however, the benefit, once obtained, lasts for a long period of time, at least up to 12 months (126). Cystoscopic studies have not demonstrated overgrowth of myoblasts nor obstruction of the lower urinary tract (129). Unfortunately, these successful results have not been confirmed yet in a randomized study.

\section{Conclusions}

This is an exciting period for those studying the biology of skeletal muscle stem cells and seeking to harness the information for clinical applications. By learning more about SCs and other mesodermal skeletal muscle progenitors, we can learn how to better use them to repair muscle. The main limitations of SCs are loss of "stemness" upon culture and an inability to cross the vessel wall for systemic delivery. Limitations for other cell types are incomplete characterization and their overall minor myogenic potency. Nevertheless, a phase I clinical trial with donor-derived MABs is planned for the end of 2010, given the fact that, because of extensive preclinical work, these cells appear at the moment as the best candidates for the cell therapy of muscular dystrophy. Moreover, the terrific prospective of deriving countless autologous, genetically corrected iPS cells from patients certainly will set the stage for future cell therapies. Finally, we should remember that SCs have already been used for clinical trials for DMD, myocardial infarction, and SUI. The last seems to be a case of success for this approach and a situation from which we may also learn in order to redirect efforts toward therapies for myocardial infarction and muscular dystrophies, which have thus far been less successful.

\section{Acknowledgments}

Work in the authors' laboratory is supported by grants from the European Community (OptiStem, Angioscaff, and MyoAmp), European Research Council, Téléthon, Association Française contre les Myopathies, Duchenne Parent Project, CureDuchenne, and the Italian Ministries of Research (FIRB) and Health.

Address correspondence to: Giulio Cossu, Division of Regenerative Medicine, San Raffaele Scientific Institute, 58 via Olgettina, 20132 Milan, Italy. Phone: 39-02-2643-4954; Fax: 39-02-2643-4621; E-mail: cossu.giulio@hsr.it.
1. Carlson BM. The regeneration of skeletal muscle. A review. Am J Anat. 1973;137(2):119-149.

2. Mintz B, Baker WW. Normal mammalian muscle differentiation and gene control of isocitrate dehydrogenase synthesis. Proc Natl Acad Sci U S A. 1967;58(2):592-598.

3. Mauro A. Satellite cells of skeletal muscle fibers. J Biophys Biochem Cytol. 1961;9:493-495.

4. Cossu G, Biressi S. Satellite cells, myoblasts and other occasional myogenic progenitors: possible origin, phenotypic features and role in muscle regeneration. Semin Cell Dev Biol. 2005;16(45):623-631.

5. Emery AE. The muscular dystrophies. Lancet. 2002;359(9307):687-695.

6. Cossu G, Sampaolesi M. New therapies for Duchenne muscular dystrophy: challenges, prospects and clinical trials. Trends Mol Med. 2007;13(12):520-526.

7. Buckingham M, Montarras D. Skeletal muscle stem cells. Curr Opin Genet Dev. 2008;18(4):330-336.
8. Gopinath SD, Rando TA. Stem cell review series: aging of the skeletal muscle stem cell niche. Aging Cell. 2008;7(4):590-598.

9. Kuang S, Gillespie MA, Rudnicki MA. Niche regulation of muscle satellite cell self-renewal and differentiation. Cell Stem Cell. 2008;2(1):22-31.

10. Shi X, Garry DJ. Muscle stem cells in development, regeneration, and disease. Genes Dev. 2006;20(13):1692-1708.

11. Sambasivan R, Tajbakhsh S. Skeletal muscle 
stem cell birth and properties. Semin Cell Dev Biol. 2007;18(6):870-882.

12. Whalen RG, Harris JB, Butler-Browne GS, Sesodia $\mathrm{S}$. Expression of myosin isoforms during notexininduced regeneration of rat soleus muscles. Dev Biol. 1990;141(1):24-40

13. Beauchamp JR, et al. Expression of CD34 and Myf5 defines the majority of quiescent adult skeletal muscle satellite cells. J Cell Biol. 2000;151(6):1221-1234.

14. Zammit PS, et al. Pax7 and myogenic progression in skeletal muscle satellite cells. J Cell Sci. 2006;119(pt 9):1824-1832.

15. Kuang S, Charge SB, Seale P, Huh M, Rudnicki MA. Distinct roles for Pax7 and Pax3 in adult regenerative myogenesis. J Cell Biol. 2006;172(1):103-113.

16. Relaix F, et al. Pax3 and Pax7 have distinct and overlapping functions in adult muscle progenitor cells. J Cell Biol. 2006;172(1):91-102.

17. Tajbakhsh S, et al. Gene targeting the myf-5 locus with nlacZ reveals expression of this myogenic factor in mature skeletal muscle fibres as well as early embryonic muscle. Dev Dyn. 1996;206(3):291-300.

18. Cornelison DD, Filla MS, Stanley HM, Rapraeger AC, Olwin BB. Syndecan-3 and syndecan-4 specifically mark skeletal muscle satellite cells and are implicated in satellite cell maintenance and muscle regeneration. Dev Biol. 2001;239(1):79-94.

19. Rosen GD, et al. Roles for the integrin VLA-4 and its counter receptor VCAM-1 in myogenesis. Cell. 1992;69(7):1107-1119

20. Cornelison DD, Wold BJ. Single-cell analysis of regulatory gene expression in quiescent and activated mouse skeletal muscle satellite cells. Dev Biol. 1997;191(2):270-283.

21. Garry DJ, et al. Myogenic stem cell function is impaired in mice lacking the forkhead/winged helix protein MNF. Proc Natl Acad Sci U S A. 2000;97(10):5416-5421.

22. Irintchev A, Zeschnigk M, Starzinski-Powitz A Wernig A. Expression pattern of M-cadherin in normal, denervated, and regenerating mouse muscles. Dev Dyn. 1994;199(4):326-337.

23. Gnocchi VF, White RB, Ono Y, Ellis JA, Zammit PS. Further characterisation of the molecular signature of quiescent and activated mouse muscle satellite cells. PLoS One. 2009;4(4):e5205

24. Blanco-Bose WE, Yao CC, Kramer RH, Blau HM. Purification of mouse primary myoblasts based on alpha 7 integrin expression. Exp Cell Res. 2001;265(2):212-220.

25. Kuang S, Kuroda K, Le Grand F, Rudnicki MA. Asymmetric self-renewal and commitment of satellite stem cells in muscle. Cell. 2007;129(5):999-1010.

26. Betsholtz C. Insight into the physiological functions of PDGF through genetic studies in mice. Cytokine Growth Factor Rev. 2004;15(4):215-228.

27. Fukada S, Higuchi S, Segawa M, Koda K, Yamamoto Y, et al. Purification and cell-surface marker characterization of quiescent satellite cells from murine skeletal muscle by a novel monoclonal antibody. Exp Cell Res. 2004;296(2):245-255.

28. Sherwood RI, et al. Isolation of adult mouse myogenic progenitors: functional heterogeneity of cells within and engrafting skeletal muscle. Cell. 2004;119(4):543-554

29. Day K, Shefer G, Richardson JB, Enikolopov G, Yablonka-Reuveni Z. Nestin-GFP reporter expression defines the quiescent state of skeletal muscle satellite cells. Dev Biol. 2007;304(1):246-259.

30. Montarras D, et al. Direct isolation of satellite cells for skeletal muscle regeneration. Science. 2005;309(5743):2064-2067.

31. Bosnakovski D, et al. Prospective isolation of skeletal muscle stem cells with a Pax7 reporter. Stem Cells. 2008;26(12):3194-3204.

32. Peault B, et al. Stem and progenitor cells in skeletal muscle development, maintenance, and therapy. Mol Ther. 2007;15(5):867-877.
33. Illa I, Leon-Monzon M, Dalakas MC. Regenerating and denervated human muscle fibers and satellite cells express neural cell adhesion molecule recognized by monoclonal antibodies to natural killer cells. Ann Neurol. 1992;31(1):46-52.

34. Price FD, Kuroda K, Rudnicki MA. Stem cell based therapies to treat muscular dystrophy. Biochim Biophys Acta. 2007;1772(2):272-283

35. Dhawan J, Rando TA. Stem cells in postnatal myogenesis: molecular mechanisms of satellite cell quiescence, activation and replenishment. Trends Cell Biol. 2005;15(12):666-673.

36. Tatsumi R, Anderson JE, Nevoret CJ, Halevy O, Allen RE. HGF/SF is present in normal adult skeletal muscle and is capable of activating satellite cells. Dev Biol. 1998;194(1):114-128.

37. Floss T, Arnold HH, Braun T. A role for FGF-6 in skeletal muscle regeneration. Genes Dev. 1997;11(16):2040-2051.

38. Musaro A. Growth factor enhancement of muscle regeneration: a central role of IGF-1. Arch Ital Biol. 2005;143(3-4):243-248.

39. Wozniak AC, Anderson JE. Nitric oxide-dependence of satellite stem cell activation and quiescence on normal skeletal muscle fibers. Dev Dyn. 2007;236(1):240-250.

40. Zammit PS, et al. Kinetics of myoblast proliferation show that resident satellite cells are competent to fully regenerate skeletal muscle fibers. Exp Cell Res. 2002;281(1):39-49.

41. Zammit PS, et al. Muscle satellite cells adopt divergent fates: a mechanism for self-renewal? J Cell Biol. 2004;166(3):347-357

42. Conboy IM, Rando TA. The regulation of Notch signaling controls satellite cell activation and cell fate determination in postnatal myogenesis. Dev Cell. 2002;3(3):397-409.

43. Shinin V, Gayraud-Morel B, Gomes D, Tajbakhsh $\mathrm{S}$. Asymmetric division and cosegregation of template DNA strands in adult muscle satellite cells. Nat Cell Biol. 2006;8(7):677-687.

44. Conboy MJ, Karasov AO, Rando TA. High incidence of non-random template strand segregation and asymmetric fate determination in dividing stem cells and their progeny. PLoS Biol. 2007;5(5):e102.

45. Le Grand F, Jones AE, Seale V, Scime A, Rudnicki MA. Wnt7a activates the planar cell polarity pathway to drive the symmetric expansion of satellite stem cells. Cell Stem Cell. 2009;4(6):535-547.

46. Partridge TA, Morgan JE, Coulton GR, Hoffman EP, Kunkel LM. Conversion of $\mathrm{mdx}$ myofibres from dystrophin-negative to -positive by injection of normal myoblasts. Nature. 1989;337(6203):176-179.

47. Cossu G, Sampaolesi M. New therapies for muscular dystrophy: cautious optimism. Trends Mol Med. 2004;10(10):516-520.

48. Collins CA, et al. Stem cell function, self-renewal, and behavioral heterogeneity of cells from the adult muscle satellite cell niche. Cell. 2005;122(2):289-301.

49. Cerletti $M$, et al. Highly efficient, functional engraftment of skeletal muscle stem cells in dystrophic muscles. Cell. 2008;134(1):37-47.

50. Sacco A, Doyonnas R, Kraft P, Vitorovic S, Blau HM. Self-renewal and expansion of single transplanted muscle stem cells. Nature. 2008;456(7221):502-506.

51. Tanaka KK, et al. Syndecan-4-expressing muscle progenitor cells in the SP engraft as satellite cells during muscle regeneration. Cell Stem Cell. 2009;4(3):217-225

52. Ikemoto $\mathrm{M}$, et al. Autologous transplantation of $\mathrm{SM} / \mathrm{C}-2.6(+)$ satellite cells transduced with microdystrophin CS1 cDNA by lentiviral vector into $\mathrm{mdx}$ mice. Mol Ther. 2007;15(12):2178-2185.

53. Cossu G. Unorthodox myogenesis: possible developmental significance and implications for tissue histogenesis and regeneration. Histol Histopathol. 1997:12(3):755-760.

54. Galli R, et al. Skeletal myogenic potential of human and mouse neural stem cells. Nat Neurosci. 2000;3(10):986-991.

55. Tajbakhsh S, et al. A population of myogenic cells derived from the mouse neural tube. Neuron. 1994;13(4):813-821.

56. Ferrari G, et al. Muscle regeneration by bone marrow-derived myogenic progenitors. Science. 1998;279(5356):1528-1530.

57. Gussoni E, et al. Dystrophin expression in the mdx mouse restored by stem cell transplantation. Nature. 1999;401(6751):390-394.

58. Ferrari G, Stornaiuolo A, Mavilio F. Failure to correct murine muscular dystrophy. Nature. 2001;411(6841):1014-1015.

59. McKinney-Freeman SL, et al. Muscle-derived hematopoietic stem cells are hematopoietic in origin. Proc Natl Acad Sci U S A. 2002;99(3):1341-1346.

60. Gussoni E, et al. Long-term persistence of donor nuclei in a Duchenne muscular dystrophy patient receiving bone marrow transplantation. J Clin Invest. 2002;110(6):807-814

61. Corbel SY, et al. Contribution of hematopoietic stem cells to skeletal muscle. Nat Med. 2003;9(12):1528-1532.

62. Camargo FD, Green R, Capetanaki Y, Jackson KA, Goodell MA. Single hematopoietic stem cells generate skeletal muscle through myeloid intermediates. Nat Med. 2003;9(12):1520-1527.

63. Torrente Y, et al. Human circulating AC133(+) stem cells restore dystrophin expression and ameliorate function in dystrophic skeletal muscle. J Clin Invest. 2004;114(2):182-195.

64. Benchaouir R, et al. Restoration of human dystrophin following transplantation of exon-skippingengineered DMD patient stem cells into dystrophic mice. Cell Stem Cell. 2007;1(6):646-657.

65. Dezawa $M$, et al. Bone marrow stromal cells generate muscle cells and repair muscle degeneration. Science. 2005;309(5732):314-317.

66. Gang EJ, et al. Engraftment of mesenchymal stem cells into dystrophin-deficient mice is not accompanied by functional recovery. Exp Cell Res. 2009;315(15):2624-2636.

67. Minasi MG, et al. The meso-angioblast: a multipotent, self-renewing cell that originates from the dorsal aorta and differentiates into most mesodermal tissues. Development. 2002;129(11):2773-2783.

68. Sampaolesi M, et al. Cell therapy of alpha-sarcoglycan null dystrophic mice through intraarterial delivery of mesoangioblasts. Science. 2003;301(5632):487-492.

69. Sampaolesi M, et al. Mesoangioblast stem cells ameliorate muscle function in dystrophic dogs. Nature. 2006;444(7119):574-579.

70. Dellavalle A, et al. Pericytes of human skeletal muscle are myogenic precursors distinct from satellite cells. Nat Cell Biol. 2007;9(3):255-267.

71. Asahara $\mathrm{T}$, et al. Isolation of putative progenitor endothelial cells for angiogenesis. Science. 1997;275(5302):964-967.

72. Pesce M, et al. Myoendothelial differentiation of human umbilical cord blood-derived stem cells in ischemic limb tissues. Circ Res. 2003;93(5):e51-e62.

73. Zheng B, et al. Prospective identification of myogenic endothelial cells in human skeletal muscle. Nat Biotechnol. 2007;25(9):1025-1034.

74. Meliga E, Strem BM, Duckers HJ, Serruys PW. Adipose-derived cells. Cell Transplant. 2007;16(9):963-970.

75. Goudenege S, et al. Enhancement of myogenic and muscle repair capacities of human adipose-derived stem cells with forced expression of MyoD. Mol Ther. 2009;17(6):1064-1072.

76. Evans MJ, Kaufman MH. Establishment in culture of pluripotential cells from mouse embryos. Nature. 1981;292(5819):154-156.

77. Thomson JA, et al. Embryonic stem cell lines derived from human blastocysts. Science. 
1998;282(5391):1145-1147

78. Yamanaka S. A fresh look at iPS cells. Cell. 2009;137(1):13-17.

79. Nishikawa S, Goldstein RA, Nierras CR. The promise of human induced pluripotent stem cells for research and therapy. Nat Rev Mol Cell Biol. 2008;9(9):725-729.

80. Park IH, et al. Disease-specific induced pluripotent stem cells. Cell. 2008;134(5):877-886.

81. Murry CE, Keller G. Differentiation of embryonic stem cells to clinically relevant populations: lessons from embryonic development. Cell. 2008;132(4):661-680.

82. Robbins J, Gulick J, Sanchez A, Howles P, Doetschman T. Mouse embryonic stem cells express the cardiac myosin heavy chain genes during development in vitro. J Biol Chem. 1990;265(20):11905-11909.

83. Sanchez A, Jones WK, Gulick J, Doetschman T, Robbins J. Myosin heavy chain gene expression in mouse embryoid bodies. An in vitro developmental study. J Biol Chem. 1991;266(33):22419-22426.

84. Bhagavati S, Xu W. Generation of skeletal muscle from transplanted embryonic stem cells in dystrophic mice. Biochem Biophys Res Commun. 2005;333(2):644-649.

85. Barberi T, et al. Derivation of engraftable skeletal myoblasts from human embryonic stem cells. Nat Med. 2007;13(5):642-648.

86. Chang H, et al. Generation of transplantable, functional satellite-like cells from mouse embryonic stem cells. Faseb J. 2009;23(6):1907-1919.

87. Dekel I, Magal Y, Pearson-White S, Emerson CP, Shani M. Conditional conversion of ES cells to skeletal muscle by an exogenous MyoD1 gene. New Biol. 1992;4(3):217-224

88. Darabi R, et al. Functional skeletal muscle regeneration from differentiating embryonic stem cells. Nat Med. 2008;14(2):134-143.

89. Bianco P, Cossu G. Uno, nessuno e centomila: searching for the identity of mesodermal progenitors. Exp Cell Res. 1999;251(2):257-263.

90. Barberi T, Willis LM, Socci ND, Studer L. Derivation of multipotent mesenchymal precursors from human embryonic stem cells. PLoS Med. 2005;2(6):e161.

91. Sakurai H, Okawa Y, Inami Y, Nishio N, Isobe K. Paraxial mesodermal progenitors derived from mouse embryonic stem cells contribute to muscle regeneration via differentiation into muscle satellite cells. Stem Cells. 2008;26(7):1865-1873.

92. Maherali N, Hochedlinger K. Guidelines and techniques for the generation of induced pluripotent stem cells. Cell Stem Cell. 2008;3(6):595-605.

93. Law PK, et al. Dystrophin production induced by myoblast transfer therapy in Duchenne muscular dystrophy. Lancet. 1990;336(8707):114-115.

94. Neumeyer AM, et al. Pilot study of myoblast transfer in the treatment of Becker muscular dystrophy. Neurology. 1998;51(2):589-592.

95. Law PK, et al. Myoblast transfer therapy for Duchenne muscular dystrophy. Acta Paediatr Jpn. 1991;33(2):206-215

96. Huard J, et al. Human myoblast transplantation between immunohistocompatible donors and recipients produces immune reactions. Transplant Proc. 1992;24(6):3049-3051.

97. Karpati G, et al. Myoblast transfer in Duchenne muscular dystrophy. Ann Neurol. 1993;34(1):8-17.

98. Law PK, et al. Feasibility, safety, and efficacy of myoblast transfer therapy on Duchenne muscular dystrophy boys. Cell Transplant. 1992;1(2-3):235-244.

99. Gussoni E, et al. Normal dystrophin transcripts detected in Duchenne muscular dystrophy patients after myoblast transplantation. Nature. 1992;356(6368):435-438.

100.Tremblay JP, et al. Results of a triple blind clinical study of myoblast transplantations without immunosuppressive treatment in young boys with Duchenne muscular dystrophy. Cell Transplant. 1993;2(2):99-112.

101. Morandi L, et al. Lack of mRNA and dystrophin expression in DMD patients three months after myoblast transfer. Neuromuscul Disord. 1995;5(4):291-295.

102. Mendell JR, et al. Myoblast transfer in the treatment of Duchenne's muscular dystrophy. N Engl J Med. 1995;333(13):832-838.

103. Miller RG, et al. Myoblast implantation in Duchenne muscular dystrophy: the San Francisco study. Muscle Nerve. 1997;20(4):469-478.

104.Skuk D, Goulet M, Tremblay JP. Use of repeating dispensers to increase the efficiency of the intramuscular myogenic cell injection procedure. Cell Transplant. 2006;15(7):659-663.

105.Partridge $T$. The current status of myoblast transfer. Neurol Sci. 2000;21(suppl 5):S939-S942.

106.Fan Y, Maley M, Beilharz M, Grounds M. Rapid death of injected myoblasts in myoblast transfer therapy. Muscle Nerve. 1996;19(7):853-860.

107. Guerette B, et al. Prevention by anti-LFA- 1 of acute myoblast death following transplantation. JImmunol. 1997;159(5):2522-2531.

108. Torrente Y, et al. Autologous transplantation of muscle-derived CD133+ stem cells in Duchenne muscle patients. Cell Transplant. 2007;16(6):563-577.

109.Atkins BZ, et al. Intracardiac transplantation of skeletal myoblasts yields two populations of striated cells in situ. Ann Thorac Surg. 1999;67(1):124-129.

110. Taylor DA, et al. Regenerating functional myocardium: improved performance after skeletal myoblast transplantation. Nat Med. 1998;4(8):929-933.

111. Pouzet B, et al. Factors affecting functional outcome after autologous skeletal myoblast transplantation. Ann Thorac Surg. 2001;71(3):844-850; discussion 850-851.

112.Reinecke H, Poppa V, Murry CE. Skeletal muscle stem cells do not transdifferentiate into cardiomyocytes after cardiac grafting. J Mol Cell Cardiol. 2002;34(2):241-249.

113.Leobon B, et al. Myoblasts transplanted into rat infarcted myocardium are functionally isolated from their host. Proc Natl Acad Sci U S A. 2003;100(13):7808-7811.

114.Smits PC, et al. Catheter-based intramyocardial injection of autologous skeletal myoblasts as a primary treatment of ischemic heart failure: clinical experience with six-month follow-up. J Am Coll Cardiol. 2003;42(12):2063-2069.
115. Menasche P, et al. Myoblast transplantation for heart failure. Lancet. 2001;357(9252):279-280.

116. Menasche P, et al. Autologous skeletal myoblast transplantation for severe postinfarction left ventricular dysfunction. $J$ Am Coll Cardiol. 2003;41(7):1078-1083.

117. Dib N, et al. Safety and feasibility of autologous myoblast transplantation in patients with ischemic cardiomyopathy: four-year follow-up. Circulation. 2005;112(12):1748-1755

118. Hagege AA, et al. Skeletal myoblast transplantation in ischemic heart failure: long-term follow-up of the first phase I cohort of patients. Circulation. 2006;114(suppl 1):I108-113.

119. Herreros J, et al. Autologous intramyocardial injection of cultured skeletal muscle-derived stem cells in patients with non-acute myocardial infarction. Eur Heart J. 2003;24(22):2012-2020.

120.Steendijk P, et al. Intramyocardial injection of skeletal myoblasts: long-term follow-up with pressure-volume loops. Nat Clin Pract Cardiovasc Med. 2006;3(suppl 1):S94-S100.

121.Pagani FD, et al. Autologous skeletal myoblasts transplanted to ischemia-damaged myocardium in humans. Histological analysis of cell survival and differentiation. I Am Coll Cardiol. 2003;41(5):879-888.

122. Menasche $\mathrm{P}$, et al. The Myoblast Autologous Grafting in Ischemic Cardiomyopathy (MAGIC) trial: first randomized placebo-controlled study of myoblast transplantation. Circulation. 2008;117(9):1189-1200.

123.Dib N, et al. One-year follow-up of feasibility and safety of the first U.S., randomized, controlled study using 3-dimensional guided catheter-based delivery of autologous skeletal myoblasts for ischemic cardiomyopathy (CAuSMIC study). JACC Cardiovasc Interv. 2009;2(1):9-16.

124. Serruys PW. Final results of a phase I/II randomized, open-label trial to evaluate intramyocardial autologous skeletal myoblast transplantation in congestive heart failure patients: The SEISMIC Trial. Paper presented at: 57th Annual Scientific Session of the American College of Cardiology; March 29-April 1 2008; Chicago, IL, USA

125.Smaldone MC, Chancellor MB. Muscle derived stem cell therapy for stress urinary incontinence. World J Urol. 2008;26(4):327-332.

126. Mitterberger M, et al. Adult stem cell therapy of female stress urinary incontinence. Eur Urol. 2008;53(1):169-175.

127. Carr LK, et al. 1-year follow-up of autologous muscle-derived stem cell injection pilot study to treat stress urinary incontinence. Int Urogynecol J Pelvic Floor Dysfunct. 2008;19(6):881-883.

128. Strasser H, et al. Transurethral ultrasonographyguided injection of adult autologous stem cells versus transurethral endoscopic injection of collagen in treatment of urinary incontinence. World J Urol. 2007;25(4):385-392.

129. Mitterberger M, et al. Autologous myoblasts and fibroblasts for female stress incontinence: a 1-year follow-up in 123 patients. BJU Int. 2007;100(5):1081-1085. 